\author{
Bartosz Szolc-Nartowski \\ Uniwersytet Gdański \\ bszolcnartowski@prawo.ug.edu.pl \\ ORCID 0000-0002-5841-3794 \\ https://doi.org/10.26881/gsp.2019.3.04
}

\title{
INTERDYKTALNA OCHRONA SWOBODY ŻEGLUGI MORSKIEJ I ZASOBÓW MORZA W PRAWIE RZYMSKIM
}

\section{Wprowadzenie}

W oparciu o źródła prawnicze można stwierdzić, że zainteresowanie ochroną wód morskich pojawiło się między ostatnimi dziesięcioleciami Republiki a połową I w. po Chr. Spotykamy wtedy pierwsze jurysprudencyjne próby definiowania brzegów morza (litora maris) oraz interwencje pretorskie służące rozciągnięciu ochrony prawnej w celu zapewnienia możliwości korzystania z morza, żeglugi oraz rybołówstwa.

Niewątpliwie przyczynę aktywności pretora stanowiły intensywny wzrost żeglugi morskiej, licząc od II w. przed Chr., związany z ekspansją terytorialną i ekonomiczną państwa rzymskiego oraz zwiększona strukturalnie i produkcyjnie aktywność, związana z pozyskiwaniem ryb i innych zwierząt morskich (Fiorentini, 2003, 278). Wybrzeża morskie były atrakcyjne nie tylko ze względu na walory krajobrazu, Rzymianie budowali tam wille dla swej przyjemności (por. Fiorentini, 1986; Lafont, 2001), ale wybrzeża stanowiły także miejsce aktywności ekonomicznej.

Zwiększona aktywność w zakresie rybołówstwa kolidować mogła z żeglugą prowadzoną przybrzeżnie i z tradycyjnymi sposobami połowu z brzegu czy łodzi. Istniała więc potrzeba zapobiegania sytuacjom konfliktowym, choćby nawet pośrednimi środkami. Jednakże żadna z form ochrony morza i brzegu morskiego nie została wprowadzona specjalnie dla ochrony korzystania z wód morskich; wszystkie oparte były na modelu interdyktów zapowiedzianych w edykcie w stosunku do innych dóbr publicznych. Przeciwko osobie, która poprowadziła groblę (molo) w morze, przysługiwał utile interdykt służący ochronie miejsc 
publicznych (D. 43.8.2.8); dogodne korzystanie z portu, przybijanie do brzegu, niezakłócony szlak żeglugi chronione były $\mathrm{w}$ oparciu o model przewidziany w edykcie dla ochrony swobody żeglugi rzecznej (wypowiedź Labeona cytowana przez Ulpiana w Komentarzu do edyktu pretorskiego - D. 43.12.1.17); ochrona wykonywania przysługującego jednostce szczególnego prawa (prioprium ius) względem morza polegała wedle relacji Paulusa na zastosowaniu interdyktu uti possidetis (D. 47.10.14); swoboda połowu oraz zastawiania sieci podlegała ochronie - nie bez kontrowersji - za pomocą actio iniuriarum (D. 43.8.3.9 i D. 47.10.13.7).

W niniejszym artykule przedstawiam zagadnienia związane z problematyką statusu prawnego morza i jego brzegów w starożytnym Rzymie, przebiegu postępowania interdyktowego oraz poszczególnych interdyktów jako narzędzi prawnych opracowanych przez rzymską jurysprudencję i pretora w celu ochrony swobody żeglugi morskiej i korzystania z brzegów morskich oraz zasobów morza.

\section{Morze i pojęcie res communes omnium}

Istniało w świecie rzymskim przekonanie, że morze i jego brzegi, tak jak woda pitna oraz powietrze, ze względu na ius naturale, należą do kategorii res communes omnium, tj. rzeczy wspólnych wszystkim ludziom, oddanych i przeznaczonych z natury do swobodnego użytku jednostek.

Punktem wyjścia do rozważań o res communes omnium jest tekst prawnika Eljusza Marciana (II-III w. po Chr.) pochodzący z jego Instytucji, a umieszczony przez kompilatorów justyniańskich w D. 1.8.2.4, a potem w Instytucjach Justyniana na początku księgi drugiej w tytule pierwszym De rerum divisione („,O podziale rzeczy"). Warto zauważyć, że fragment tekstu Marciana umieszczony w Digestach nie zawiera $\mathrm{w}$ wyliczeniu rzeczy publicznych (res publicae).

D. 1.8.2. Marcianus libro tertio institutionum pr: Quaedam naturali iure communia sunt omnium, quaedam universitatis, quaedam nullius, pleraque singulorum, quae variis ex causis cuique adquiruntur. 1. Et quidem naturali iure omnium communia illa sunt: aer, aqua profluens, et mare, et per hoc litora maris. - „Niektóre rzeczy według prawa naturalnego są współwłasnością wszystkich, niektóre własnością zbiorowości, inne natomiast nie należą do nikogo, większość jednak należy do poszczególnych osób, które nabywają je różnymi sposobami. 1. Te zaś, które według prawa naturalnego wspólne są wszystkim [ludziom]: powietrze, woda pitna, morze a przez to brzegi morza".

I. 2.1 pr:: Quaedam enim naturali iure communia sunt omnium, quaedam publica, quaedam universitatis, quaedam nullius, pleraque singulorum, quae variis ex causis cuique adquiruntur, sicut ex subiectis apparebit. 1. Et quidem naturali iure communia sunt omnium haec: aer et aqua profluens et mare et per hoc litora maris. Nemo igitur ad litus maris accedere prohibetur, dum tamen villis et monumentis et aedificiis abstineat, quia non sunt iuris gentium, sicut et mare. „Niektóre rzeczy według prawa naturalnego są wspólne wszystkim, niektóre publiczne, niektóre własnością zbiorowości, inne natomiast nie należą do nikogo, większość 
jednak należy do poszczególnych osób, które nabywają je różnymi sposobami, jak to się z tego, co podajemy w dalszym toku wykładu, okaże. 1. Te zaś [rzeczy] według prawa naturalnego wspólne są wszystkim [ludziom]: powietrze i woda pitna, i morze, i przez to brzegi morza. Nikomu nie zabrania się dostępu do brzegu morza, jeśli tylko powstrzyma się od wchodzenia do posiadłości wiejskich, grobowców i budynków, ponieważ nie podlegają one prawu narodów, tak jak morze".

Romaniści przedstawiali różne opinie co do kategorii res communes omnium. Dawniejszą literaturę zebrał w tej mierze Vicenzo Arangio-Ruiz $(2012,171)$; nowszą podaje Maria Casola (2017, 2-3). Najpierw kategorię res communes omnium przypisywano interwencji prawników justyniańskich, którzy mieliby dokonać interpolacji w tekście Marciana, później uznano fragment za oryginalny, pogląd Marciana uważano jednak za odosobniony (Talamanca, 1990, 382-383). Odnotowania wymaga zdanie Giuseppe Grosso, wedle którego Marcian nie był twórcą kategorii res communes omnium. Pojęcie to funkcjonowało już w jego czasach w celu przedstawienia dóbr zdolnych zaspokoić potrzeby wspólnoty i przeznaczonych do wspólnego użytku (Grosso, 1974, 25). Francesco Sini podkreślał funkcjonalność kategorii res communes przeznaczonej do ochrony interesów wspólnych oraz przysługujących jednostce we wspólnocie (Sini, 2008) ${ }^{1}$. W terminologii prawniczej res communes oznaczałyby rzeczy, które nie należą do osób prywatnych ani wspólnot politycznych, lecz są przeznaczone do korzystania przez wszystkich ludzi. Z tego punktu widzenia res communes omnium zajmowały pozycję odmienną od res publicae. Ich usunięcie bowiem z powszechnego użytku nie byłoby możliwe, co z kolei mogło zdarzyć się w przypadku rzeczy należącej do kategorii res publicae. Podnoszone zarzuty dotyczące teoretycznej wadliwości jurysprudencyjnej koncepcji, uznającej możliwość istnienia praw wielu osób o tej samej treści na jednej rzeczy, zostały oddalone przez przedstawicieli współczesnej romanistyki, dostrzegającej w tym rozwiązaniu szczęśliwą intuicję rzymskich jurystów. Dostrzegli oni i opracowali koncepcję praw do rzeczy, które nie mogą ze swej natury przynależeć wyłącznie do jednostki czy wspólnoty jednostek i przez to charakteryzują się swoistym reżimem prawnym, będąc dobrem całej ludzkości (Casola, 2017, 4). W ten sposób stworzyli podstawy dla prawnej koncepcji niektórych współczesnych praw człowieka, np. prawa do czystego środowiska.

Morze i jego brzegi ujmowane były często łącznie, odmiennie niż rzeki i ich brzegi. Widać to w szczególności w myśli Marciana. Podleganie morza i jego

\footnotetext{
1 Autor zaznacza również, że Eljusz Marcianus pozostawał pod wpływem literatury i pism filozoficznych, w tym Plauta, Cycerona i Wergiljusza, por: Plaut. Rud. 975 (4.3.5): Mare quidem commune certost omnibus.; Cic. Pro Roscio 26.72: Etenim quid tam est commune quam spiritus vivis, terra mortuis, mare fluctuantibus, litus eiectis? Verg. Aen. 7.228-230: Diluvio ex illo tot vasta per aequora vecti / dis sedem exiguam patriis litusque rogamus / innocuum et cunctis undamque auramque patentem; Sen. De ben. 4.28: Deus quoque quaedam munera in universum humano generi dedit, a quibus excluditur nemo; nec enim poterat fieri ut ventus bonis viris secundus esset, contrarius malis: commune autem bonum erat, patere commercium maris, et regnum humani generis relaxari. Bliższa analiza rzymskich źródeł literackich odnoszących się do morza jako bonum commune zob. Ortu (2017).
} 
brzegów dyscyplinie ius gentium, stanowi u niego podstawę ich jednolitego traktowania.

D. 1.8.4. Marcianus libro tertio institutionum. pr.: Nemo igitur ad litus maris accedere prohibetur piscandi causa, dum tamen ullius et aedificiis et monumentis abstineatur, quia non sunt iuris gentium sicut et mare: idque et divus pius piscatoribus formianis et capenatis rescripsit. 1. Sed flumina paene omnia et portus publica sunt. - „pr. Nikomu nie zabrania się dostępu do brzegu morskiego, jeśli chciałby łowić ryby. Istnieje jednak zakaz wchodzenia do domów i grobowców, ponieważ nie podlegają one prawu narodów, tak jak morze. I to boski Pius odpisał w reskrypcie rybakom Formii i Kapeny. 1. Lecz prawie wszystkie rzeki i porty są własnością publiczną".

Niektórzy juryści uważali jednak, że brzegi morskie przynależały do kategorii res publicae, a więc rzeczy przeznaczonych do użytku publicznego, jak drogi publiczne, porty, rzeki żeglowne.

D. 50.16.96. Celsus libro vicensimo quito digestorum. pr.: Litus est, quousque maximus fluctus a mari pervenit: idque Marcum Tullium aiunt, cum arbiter esset, primum constituisse. - „Brzeg rozciąga się tak daleko, jak daleko dociera największa fala od strony morza. I mówi Marcus Tuliusz [Cyceron], że podobno Gallus Aquilius jako pierwszy to ustalił, kiedy miał pełnić funkcje sędziego".

D. 50.16.112. Iavolenus libro undecimo ex Cassio: Litus publicum est eatenus, qua maxime fluctus exaestuat. Idemque iuris est in lacu, nisi is totus privatus est. - „Brzeg morski stanowiący własność publiczną rozciąga się tak daleko, jak daleko sięga fala. Ta sama norma prawna dotyczy jeziora, chyba że całkowicie jest ono własnością prywatną".

D. 43.8.3. Celsus libro trigensimo nono digestorum. pr.: Litora, in quae populus Romanus imperium habet, populi Romani esse arbitror. 1. Maris communem usum omnibus hominibus, ut aeris, iactasque in id pilas eius esse qui iecerit: sed id concedendum non esse, si deterior litoris marisve usus eo modo futurus sit. - „pr. Uważam, że brzegi morskie, co do których lud rzymski sprawuje imperium, należą do ludu rzymskiego. 1. Morze podobnie jak powietrze jest do wspólnego użytku wszystkich ludzi, a ustawione w nim pale stanowią własność tego, kto je ustawił. Nie należy jednak pozwalać na takie działanie, jeśli miałoby to utrudnić korzystanie z brzegu czy morza".

D. 18.1.51. Paulus libro vincesimo primo ad edictum.: Litora, quae fundo vendito coniuncta sunt, in modum non computantur, quia nullius sunt, sed iure gentium omnibus vacant: nec viae publicae aut loca religiosa vel sacra. - „Brzegi morza, które graniczą ze sprzedawanym gruntem, nie są wliczane do jego powierzchni, ponieważ nie należą do niego, lecz na mocy ius gentium dostępne są dla wszystkich, jak i drogi publiczne, miejsca otoczone czcią religijną czy uświęcone".

D. 39.2.24. Ulpianus libro octogensimo primo ad edictum. pr.: Fluminum publicorum communis est usus, sicuti viarum publicarum et litorum. In his igitur publice licet cuilibet aedificare et destruere, dum tamen hoc sine incommodo cuiusquam fiat. - „pr. Rzeki są przedmiotem wspólnego użytku, tak jak drogi publiczne i brzegi morza. Na tych zatem terenach każdemu wolno budować i burzyć, dopóki nie dzieje się to ze szkodą dla innych". 
Sprzeczność poglądów między jurystami być może jednak jest pozorna. Interesującą interpretację wypowiedzi Celsusa zawartej w D. 43.8.3 pr. proponuje Paolo Maddalena $(2012,36)$. Autor sądzi, że w stosunku do brzegów morza ludowi rzymskiemu przysługiwało imperium, na mocy którego uprawniony był do regulowania zasad wspólnego korzystania z brzegu.

Żyjący przed Marcianem jurysta Neracjusz (I-II w. po Chr.) wyjaśniał, że określenie litora publica (brzegi publiczne) nie oznacza rzeczy, które znajdują się w majątku publicznym (in patrimonio populi). Pozycję prawną brzegów morskich porównał do statusu prawnego ryb i dzikiej zwierzyny, przed zawładnięciem niestanowiących niczyjej własności. Ich szczególny status prawny wynika z tego, że należą one do rzeczy pierwotnie ukształtowanych przez naturę (primum a natura prodita sunt).

D. 41.1.14. Neratius libro quinto membranarum. pr:: Quod in litore quis aedificaverit, eius erit: nam litora publica non ita sunt, ut ea, quae in patrimonio sunt populi, sed ut ea, quae primum a natura prodita sunt et in nullius adhuc dominium pervenerunt: nec dissimilis condicio eorum est atque piscium et ferarum, quae simul atque adprehensae sunt, sine dubio eius, in cuius potestatem pervenerunt, dominii fiunt. - „pr. To, co ktoś zbuduje na brzegu morza, należeć będzie do niego. Brzeg morza uznaje się bowiem za grunt publiczny nie $\mathrm{w}$ takim sensie jak rzeczy, które stanowią majątek publiczny, ale tak jak to, co pierwotnie ukształtowała sama natura i co nie stało się jeszcze czyjąś własnością. Ich status podobny jest do sytuacji ryb i dzikiej zwierzyny, które, gdy tylko zostaną złapane, bez wątpienia stają się własnością tego, pod którego władzę weszły".

Pierwotny charakter brzegów morskich rozstrzyga także o tym, że po zniszczeniu posadowionego na nich budynku wracają do swego pierwotnego stanu i znów pozostają dobrem niebędącym niczyją własnością.

D. 41.1.14.1. Neratius libro quinto membranarum: Illud videndum est, sublato aedificio, quod in litore positum erat, cuius condicionis is locus sit, hoc est utrum maneat eius cuius fuit aedificium, an rursus in pristinam causam reccidit perindeque publicus sit, ac si numquam in eo aedificatum fuisset. quod propius est, ut existimari debeat, si modo recipit pristinam litoris speciem. - „Zobaczmy, jeśli budynek, który został wzniesiony na brzegu, zostanie zniszczony, jaka będzie sytuacja prawna miejsca, na którym został wzniesiony: czy zostanie ono własnością tego, który wzniósł budynek, czy też powróci do poprzedniej sytuacji i stanie się publicznym, tak jakby nigdy nie wzniesiono na nim budynku. Właściwszy jest drugi pogląd, zakładając, że utrzyma swoje dawne położenie jako część brzegu".

Pozyskiwanie zasobów morza mogło stanowić pewną uciążliwość dla właścicieli gruntów nadmorskich. W D. 8.4.13 pr. umieszczony został fragment Opiniones Ulpiana, $\mathrm{w}$ którym relacjonuje on przypadek kontraktu sprzedaży gruntu, z klauzulą, w której sprzedawca zastrzegł sobie na rzecz zatrzymanego sąsiedniego gruntu, by nie można było wzdłuż jego brzegów prowadzić połowów tuńczyka.

D. 8.4.13. Ulpianus libro sexto opinionum. pr.: Venditor fundi Geroniani fundo Botriano, quem retinebat, legem dederat, ne contra eum piscatio thynnaria exerceatur. Quamvis mari, quod natura omnibus patet, servitus imponi privata lege non potest, quia tamen bona fides contrac- 
tus legem servari venditionis exposcit, personae possidentium aut in ius eorum succedentium per stipulationis vel venditionis legem obligantur. - „Sprzedawca gruntu geroniańskiego zastrzegł w umowie sprzedaży na rzecz gruntu botriańskiego, który zatrzymał dla siebie, by nie prowadzono wzdłuż jego brzegów połowów tuńczyka. Choć w prywatnej umowie nie można nałożyć służebności na morze, które ze swej natury jest dla wszystkich otwarte, to jednak skoro dobra wiara wymaga, by przestrzegać dodatkowych postanowień umowy sprzedaży, posiadacze lub ci, którzy jako następcy wejdą w ich prawa, ponoszą odpowiedzialność na podstawie klauzuli stypulacji bądź kontraktu sprzedaży".

Mimo że nakładanie w umowie służebności na morze było niedopuszczalne przecież stanowiło ono z natury dobro dla wszystkich otwarte - dobra wiara wymagała jednak, by nabywca aktualny i kolejni przestrzegali dodatkowych klauzul umowy ${ }^{2}$. Nie znamy przyczyn, dla których sprzedawca domagał się obciążenia gruntu. Być może chodziło o zapewnienie walorów estetycznych krajobrazu, spokoju, który mógłby być zakłócany aktywnością rybacką. Mogło iść także o wyeliminowanie konkurencji gospodarczej. Warto jeszcze wspomnieć o krytycznej uwadze podniesionej w literaturze romanistycznej, że w istocie służebność nie byłaby nałożona na morze, lecz na grunt geroniański (Biondi, 1954, 193) ${ }^{3}$.

Na podstawie powyższych materiałów źródłowych i naszych obserwacji spróbujmy określić status prawny morza i jego brzegów. Morze i brzegi morza stanowiły dobro wspólne i jako takie przeznaczone były i otwarte dla użytku każdego. Treść tego użytku mogła być rozmaita, zaś prawo jednostki do korzystania ograniczone było o tyle, że nie mogło negować prawa o tej samej treści przysługującego innej jednostce. W oparciu o te spostrzeżenia juryści i pretorzy opracowali środki prawne służące ochronie swobody żeglugi i wykorzystania zasobów morza. Wśród tych środków niepoślednią funkcję pełniły interdykty.

\section{Interdykty i postępowanie interdyktowe}

Interdykt był to nakaz określonego postępowania albo zaniechania działania, zobowiązujący stronę (strony) do jego przestrzegania, gdyby znalazła się w położeniu określonym przez interdykt ${ }^{4}$.

\footnotetext{
2 W literaturze polskiej fragment w kontekście wymogów dobrej wiary omówiony został w: Dajczak (1998), 101-102.

3 Wątpliwości budzi wskazanie na umowę jako źródło powstania służebności; wskazanie na stypulację sugerować może, że chodziło o służebność ustanawianą na gruncie prowincjonalnym, który to sposób stał się powszechny w prawie justyniańskim; por. G. 2.31.

4 G. 4.139: (...) et in summa aut iubet aliquid fieri aut fieri prohibet. Formulae autem et verborum conceptiones, quibus in ea re utitur, interdicta decrtave cocantur. - „(...) I w ogólności albo rozkazuje coś uczynić, albo zakazuje czynić. Formuły zaś i ułożenia słów, które są tu w użyciu, nazywają się interdyktami i dekretami". Według Biscardi (2002), 18 wyrażenie formulae et verborum conceptiones nie stanowi u Gaiusa hendiadys, tj. figury stylistycznej, polegającej na przedstawieniu jednego pojęcia przez dwa wyrazy połączone; verborum conceptiones użyte są w znaczeniu odpowiednich słów do konkretnej sytuacji faktycznej, w przeciwstawieniu do certa verba powództw legisakcyjnych, czyli uprzednio określonych, sztywnych formuł słownych.
} 
Postępowanie interdyktowe oparte było na autorytecie i imperium najwyższych rzymskich urzędników ${ }^{5}$. W nauce prawa rzymskiego panuje zgoda co do tego, że powodem wprowadzenia tego postępowania była konieczność podjęcia działań w sposób szybki, energiczny i z odpowiednią powagą, w celu ochrony dóbr publicznych. Uważa się zresztą, że najstarsze interdykty miały właśnie na celu dobra publiczne (Di Lella, 2004, 193) ${ }^{6}$.

Interdykty prohibitoryjne to te zakazujące określonego zachowania adresatowi. Jusrysprudencja zauważyła, że można je podzielić na jednostronne (simplicia) i dwustronne (duplicia), biorąc pod uwagę role procesowe stron 7 . Przy jednostronnych powodem był ten, który domagał się, by pewne zdarzenie nie nastąpiło, pozwanym ten, kto usiłował coś czynić. Natomiast przy dwustronnych położenie każdego z uczestników sporu było jednakowe i każdy z nich przyjmował rolę tak pozwanego, jak i powoda, zaś słowa pretora adresowane były do obydwu. Jednostronnymi były np. te, w których pretor zakazywał pozwanemu określonego zachowania w miejscu uświęconym albo w publicznej rzece lub u jej brzegu, zaś dwustronnymi - interdykty posesoryjne uti possidetis i utrubi.

Ochronie miejsc publicznych (loca publica: areae, agri, insulae, viae publicae, itinera publica ${ }^{8}$ ) służyły interdykty prohibitoryjne, posiadające często tę cechę, że mógł je wnieść ktokolwiek (quivis ex populo) ${ }^{9}$. Jednak, mimo że przedmiotem ochrony było dobro publiczne, nakaz magistratury wydany był na wniosek osoby prywatnej, która znajdowała się w sytuacji sporu z drugą osobą prywatną ${ }^{10}$. Trafnie zauważa Luigi Di Lella $(2004,194)$, że w postępowaniu interdyktowym stronami są zawsze osoby prywatne, także kiedy interes podlegający ochronie ma charakter publiczny.

\footnotetext{
5 Por. G. 4.139: Certis igitur ex causis praetor aut proconsul principaliter auctoritatem suam finiendis controversiis interponit. - "W określonych wypadkach pretor lub prokonsul używa głównie swej powagi dla położenia kresu sporom". Gaius wydaje się, moim zdaniem, podkreślać, że moc powagi urzędu pretora sprawia, że interdykty spełniają swoją funkcję. Por. także D. 43.8.7. Iulianus libro quadragensimo octavo digestorum: Sicut is, qui nullo prohibente in loco publico aedificaverat, cogendus non est demolire, ne ruinis urbs deformetur, ita qui adversus edictum praetoris aedificaverit, tollere aedificium debet: alioqui inane et lusorium praetoris imperium erit. - “Tak jak ten, kto zbudował coś w miejscu publicznym bez sprzeciwu ze strony innych nie powinien być zmuszany do zburzenia tego, aby nie oszpecać miasta ruinami, tak ten, kto zbudował wbrew edyktowi pretora, powinien rozebrać budowlę. $\mathrm{W}$ przeciwnym razie władza pretora będzie pozorna i śmieszna". Julian zatem kładzie nacisk na mający swe źródło w imperium pretora obligacyjny charakter interdyktu. Por. Biscardi (2002), 24.

6 Na temat pochodzenia ochrony interdyktalnej zob. Gandolfi (1955), 120 i nn.; Capogrosso Colognesi (1971). Ogólnie na temat charakteru ochrony interdyktalnej i postepowania interdyktalnego zob. Biscardi (2002), 9-98.

7 Por. G. 4.158-160.

8 Por. wypowiedź Labeona cytowaną przez Ulpiana w D. 43.8.2.3.

9 We fragmencie Ulpiana przekazanym w D. 43.8.2.34 znajdujemy sformułowanie interdictum populare. Por. Sitek (1999), 34-39; Kamińska (2017), 2-3.

10 Por. D. 47.10.14. Paulus libro testio decimo ad Plautium: (...) ad privatas enim causas accomodata interdicta sunt, non ad publicas. - „Interdykty przeznaczone są do spraw prywatnych, nie publicznych".
} 
Interdyktów służących ochronie miejsc publicznych było wiele. W edykcie pretorskim, zrekonstruowanym przez Otto Lenela (1927, 458 i nn.) występują: interdictum ne quid in loco publico vel itinere fiat; interdictum quod in itinere publico factum erit, ut restituatur; interdictum ut via publica itinereve publico ire agere liceat; interdictum de loco publico fruendo; interdictum de via publica et itinere publico recifiendo.

Przedmiotem ochrony jest tu pożytek (utilitas) osoby prywatnej jako takiej, jak i użytkownika miejsca publicznego. Wprawdzie interdictum ne quid in loco publico vel itinere fiat uwzględnia zarówno interes prywatny, jak i publiczny ${ }^{11}$, jednak jego udzielenie stanowi realizację ochrony prawa jednostki do korzystania z miejsca publicznego. Ochrona nie jest realizowana wprost przez inicjatywę organów państwowych, lecz inicjatywa ta jest pozostawiona samym obywatelom jako użytkownikom miejsc publicznych. Procedura interdyktowa zaczyna się wnioskiem o udzielenie interdyktu i kończy się nakazem skierowanym do innej osoby prywatnej. W ten sposób tłumaczy się tzw. popularny charakter wielu interdyktów (Di Lella, 2004, 195). Przychylam się do tezy, że takie ukształtowanie sposobu reakcji prawnej jest wyrazem określonej koncepcji porządku prawnego, zawierającego zespół instrumentów prawnych bezpośrednio skierowanych na zapobieganie i rozwiązywanie konfliktów między osobami prywatnymi (Di Lella, 2004, 195).

\section{Przeciwko temu, kto prowadzi groble w morze}

Ulpian we fragmencie swojego Komentarza do edyktu ne quid in loco publico itinere fiat zaznacza, że w stosunku do osoby, która wznosiłaby groblę ${ }^{12} \mathrm{w}$ morze, przysługuje interdykt analogiczny(utile), tj. oparty na modelu ne quid in loco publico.

D. 43.8.2.8. Ulpianus libro sexagensimo octavo ad edictum: Adversus eum, qui molem in mare proi[e]cit, interdictum utile [competit] ei, cui forte haec res nocitura sit: si autem nemo damnum sentit, tuendus est is, qui in litore aedificat vel molem in mare iacit. - „Przeciwko osobie, która poprowadziła groblę w morze, przysługuje analogiczny interdykt temu, komu ta rzecz może zaszkodzić. Jeśli zaś nikt nie doznaje szkody, należy wziąć w obronę tego, kto buduje na brzegu lub prowadzi groble w morze".

Legitymowana do postulowania edyktu była wyłącznie osoba prywatna, która obawiała się pogorszenia swojej sytuacji możności „korzystania z morza”. Z drugiej części fragmentu wynika, że interdykt przysługiwał nie tylko przeciw-

11 D. 43.8.2.2. Ulpianus libro saxagensimo octavo ad edictum: (...) Et tam publicis utilitatibus quam privatorum per hoc prospicitur. Szczegółowo na temat interesu publicznego i interesów jednostek w kontekście interdyktu ne quid in loco por. Kamińska (2017).

12 Labeo zalicza do nakładów koniecznych poniesionych na dobra posagowe groblę (moles) skonstruowaną w celu ochrony budynku wzniesionego na brzegu morskim lub rzeki, por. D. 25.1.1.3. Ulpianus libro trigesimo sexto ad Sabinum: Inter necessarias impensas esse Labeo ait moles in mare vel flumen proiectas. (...). Por. Fiorentini (2003), 331, przyp. 114. 
ko temu, kto budował groblę, ale także przeciwko temu, kto wznosił jakąkolwiek budowlę na brzegu.

Wiemy, że morze, a w szczególności brzegi morza nie były uznawane za loca publica w ścisłym znaczeniu. Stąd pretor wydawał interdykt w oparciu o model ne quid in loco publico. Taka praktyka jest wyrazem tendencji do asymilacji morza i brzegów morskich do innych miejsc publicznych (por. na ten temat Fiorentini, 2003, 340-342). Podobieństwo wynika z faktu, że morze i jego brzegi ze swojej natury dostępne są dla wszystkich.

Postulować wydanie interdyktu można było w sytuacji, gdy obiekt miał zostać wybudowany lub był w trakcie budowy. Środek ten miał więc wyłącznie charakter prohibitoryjny ${ }^{13}$. W krytycznym opracowaniu tekstu Digestów T. Mommsena i P. Krügera zasugerowano błąd w pisowni - w oryginalnym tekście Ulpiana zamiast czasu przeszłego - proiecit, czasownik ten, oznaczający tu poprowadzenie budowli w morze, użyty był w czasie teraźniejszym, w znaczeniu „wysuwa”, „Wznosi”14. Wyrażono także pogląd, że czasownik competit w znaczeniu „przysługuje", określający legitymację czynną do postulowania wydania interdyktu jest formalną interpolacją, w oryginalnym tekście zamiast czasownika competere użyto czasownika dare („dawać”) (Luzatto, 2004, 165, przyp. 2).

Przesłanką wydania interdyktu był stan potencjalnej szkody (damnum), której doznać miałby wnioskodawca wskutek wzniesienia grobli lub innej budowy na brzegu morskim. W edykcie użyto sformułowania ei, cui forte haec res nocitura est. Forma czasu przyszłego wyrazu nocitura potwierdza, że szkoda dopiero miałaby nastąpić wskutek budowy obiektu. Słowo forte („przypadkiem, możliwie, może”) wydaje się wskazywać, że już sama możliwość wystąpienia szkody mogła się okazać wystarczająca.

W jaki sposób rozumiano pojęcie damnum na gruncie tekstu edyktu ne quid in loco? Ulpian wyjaśnia, że szkoda polegała na utracie korzyści, którą ktoś czerpał z miejsca publicznego.

D. 43.8.2.8.11. Ulpianus libro sexagensimo octavo ad edictum: Damnum autem pati videtur, qui commodum amittit, quod ex publico consequebatur, qualequale sit. 12. Proinde si cui prospectus, si cui aditus sit deterior aut angustior, interdicto opus est. - „Uważa się zaś, że doznaje szkody ten, kto traci korzyść, którą czerpał z miejsca publicznego, jakakolwiek by ona była. 12. Dlatego, kiedy komuś pogarszany albo ograniczany jest widok albo dostęp, konieczne jest zastosowanie interdyktu".

Prawdopodobnie ze względu na to, że interdykt ne quid in loco stosowano do sytuacji poprowadzenia grobli w morze lub wzniesienia obiektu na brzegu morskim jedynie odpowiednio, Ulpian nie precyzuje, czy szkoda polegać musi na pogorszeniu warunków żeglugi morskiej. Uznać należy, że jakiekolwiek ogra-

13 Por. ad prohibendum eum reficere - Aristo w D. 43.8.2.7.

14 Zob. D. 48.2.8, przyp. 8. 
niczenie korzyści, którą ktoś czerpie w związku z aktywnością prowadzoną na morzu czy brzegach morskich, może uzasadniać wydanie interdyktu.

Ochronie podlega tu dobro, którym jest swoboda korzystania z morza, ale w takich granicach, by nie wyrządzać szkody drugiej osobie, innymi słowy: w ten sposób, by nie ograniczać możliwości korzystania z morza i brzegów morskich drugiej osobie. Idea ta widoczna jest w końcowym fragmencie tekstu: si autem nemo damnum sentit, tuendus est is, qui in litore aedificat vel molem in mare iacit. Jeśli wskutek budowli nie grozi szkoda, wznoszenie obiektu na brzegu czy przy brzegu morskim nie tylko jest dozwolone, ale podlega ochronie ${ }^{15}$.

\section{W sprawie utrudnień żeglugi morskiej - projekt Labeona?}

Ulpian we fragmencie Komentarza do edyktu omawia zapowiedź pretora udzielenia interdyktu w przypadkach utrudnień żeglugi rzecznej (de fluminibus, ne quid on flumine publico ripave eius fiat, quo peius navigetur). W tekście jurysty znajduje się odwołanie do opinii Labeona, przywołującego słowa zapowiedzi edyktu stanowiącego reakcję na możliwe utrudnienia żeglugi morskiej.

D. 43.12.1.17. Ulpianus libro sexagensivo octavo ad edictum: Si in mari aliquid fiat, Labeo [ait] competere tale interdictum: 'ne quid in mari inve litore' 'quo portus, statio iterve navigio deterius fiat'. - „Jeżeli dokonywano by czegoś na morzu, Labeo twierdzi, że przysługuje taki interdykt: 'aby ani na morzu, ani na jego brzegach' (nie zostałoby uczynione), wskutek czego port, przybijanie do brzegu czy żegluga nie stałyby się mniej dogodne”.

Nie znamy w całości treści interdyktu wspomnianego przez Labeona. Umiejscowienie wypowiedzi Labeona $\mathrm{w}$ toku przedstawienia przez Ulpiana problematyki związanej z interdyktem ne quid in flumine publico świadczyć może o związkach logiczno-strukturalnych między oboma interdyktami. Być może, jak twierdzi M. Fiorentini (2003, 347-348), Labeon sugeruje własną formułę interdyktu, którego miałby udzielić pretor w formie interdictum utile. Za taką interpretacją przemawia fakt, że w przedstawieniu Ulpiana brak jest osobnego interdyktu słu-

\footnotetext{
15 Możliwość wznoszenia obiektów na brzegach morskich potwierdzona jest u innych jurystów; Celsus podnosi, że jednak w ten sposób nie można pogarszać użytku (deterior usus) innych osób, por. cyt. wyżej D. 43.8.3 pr. Podobnie Scaevola wskazuje na ograniczenia płynące z charakteru usus publicus, D. 43.8.4. Scaevola libro quinto responsorum: Respondit in litore iure gentium aedificare licere, nisi usus publicus impediretur. - „Odpowiedział, że zgodnie z ius gentium wznosić budynki na brzegu morza, o ile nie utrudniłoby to jego publicznego użytku”. Pomponiusz jednak zaznacza, że przed budową należałoby otrzymać dekret pretora, w którym zezwoliłby na wzniesienie budowli. Zob. D. 41.1.50. Pomponius libro sexto ex Plautio: Quamvis quod in litore publico vel in mari exstruxerimus, nostrum fiat, tamen decretum praetoris adhibendum est, ut id facere liceat: immo etiam manu prohibendus est, si cum incommodo ceterorum id faciat: nam civilem eum actionem de faciendo nullam habere non dubito. - „Chociaż to, co wzniesiemy na brzegu morskim, który jest wspólny dla wszystkich albo na samym morzu, staje się naszą własnością, to jednak należy otrzymać postanowienie pretora zezwalające nam na dokonanie tego. Co więcej, jeśli ktoś dokonałby tego ze szkodą dla pozostałych, należy mu tego zabronić, nawet siłą. Nie mam bowiem wątpliwości, że nie przysługuje mu żadna skarga przewidziana przez ius civile". Co do podejrzeń interpolacji tekstu por. Fiorentini (2003), 335 i nn.
} 
żącego ochronie morza i brzegów morskich. Być może w czasach Ulpiana brak było środków pretorskich, służących zapewnieniu swobody żeglugi morskiej. Jurysta zaś, widząc potrzebę interwencji, proponował rozstrzygnięcie oparte na sprawdzonych rozwiązaniach interdyktu ne quid in flumine publico.

Zestawiając stosowany analogicznie interdykt ne quid in loco publico z treścią interdyktu ne quid in mari, dojść możemy do wniosku, że ten drugi był bardziej szczegółowy. Miał na celu rozwiązanie konkretnych problemów związanych z utrudnieniem szlaku dla żeglugi, przybijaniem do brzegu, korzystaniem z portu. Brak w nim wzmianki o damnum. Zapewne wynika to z tego, że utrudnienie żeglugi stanowi jednocześnie szkodę w rozumieniu utraty korzyści z użytku (deterior usus). Cel publiczny wydaje się być tu bardziej eksponowany niż w przypadku ne quid in loco publico. Przytaczany przez Labeona interdykt wydaje się mieć charakter prohibitoryjny. Wskazywać może na to miejsce, które zajmuje wzmianka o nim w przyjętym przez Ulpiana porządku omówienia interdyktu ne quid in flumine publico. Ulpian bowiem w następnej kolejności omawia interdykt restytutoryjny, dotyczący tej samej sytuacji. Niewykluczone, że w sytuacji określonych zrealizowanych działań na morzu czy brzegu morskim ubiegać by się można o edykt restytutoryjny, jeśli pretor nie podjąłby innych działań z urzędu.

\section{Si maris prioprium ius ad aliquem pertinet - szczególne uprawnienia na morzu}

Zachowany w Digestach Justyniana fragment księgi trzynastej Komentarza do edyktu Paulusa informuje, że jednostka mogła dysponować wyłącznym tytułem do korzystania z morza.

D. 47.10.14. Paulus libro tertio decimo ad Plautium: Sane si maris proprium ius ad aliquem pertineat, uti possidetis interdictum ei competit, si prohibeatur ius suum exercere, quoniam ad privatam iam causam pertinet, non ad publicam haec res, utpote cum de iure fruendo agatur, quod ex privata causa contingat, non ex publica. Ad privatas enim causas accommodata interdicta sunt, non ad publicas. - „Oczywiście, jeśli ktoś miałby jakieś szczególne uprawnienie względem morza, przysługuje mu interdykt uti possidetis, gdyby zabraniano mu jego wykonywania, ponieważ rzecz tyczy się już sprawy prywatnej, nie publicznej, tak jakby sprawa dotyczyła prawa korzystania, dla którego istnieje podstawa prywatna, nie publiczna. Interdykty odnoszą się bowiem do spraw prywatnych, nie publicznych".

Fragment ten zamieszczony został przez kompilatorów justyniańskich pod tytułem, gdzie przedstawione są zagadnienia dotyczące skargi z tytułu umyślnego naruszenia osobowości (actio iniuriarum). Interdykt uti possidetis dotyczył nieruchomości i służył do utrzymania naruszonego posiadania (D. 43.17). Wydany nakaz pretora skierowany był do obydwu stron sporu. W sprawie prywatnych korzyści (prioprium ius), które ktoś czerpałby z morza, przysługuje zdaniem jurysty interdykt służący ochronie posiadania. Nie chodzi tu jednak o ochronę uprawnień otrzymanych przez jednostkę ze strony państwa w drodze koncesji, np. wyłącznych uprawnień do połowu ryb na określonym obszarze morza. W ta- 
kim przypadku przysługiwałby interdykt de loco publico fruendo (por. Fiorentini, 2003, 351 i nn.; Klingenberg, 2004; Purpura, 2004, 178). Chodzi tu raczej o sytuację zajęcia odcinka morskiego, np. przez założenie zastawnych sieci czy hodowli (farmy) ostryg ${ }^{16}$. Jeśli taka aktywność nie ogranicza korzystania z morza przez innych (brak przesłanki damnum), nie tylko jest dozwolona, ale podlega ochronie na podstawie interdyktu uti possidetis (Purpura, 2004, 178).

\section{Ochrona wolności połowów - interdykt czy actio iniuriarum?}

Odmiennie rozwiązano kwestię działań sprowadzających się do zakazu czy przeszkodzenia (prohibitio) w uprawianiu rybołówstwa czy żeglugi. W tych przypadkach nie przysługiwał interdykt, lecz inny środek prawny.

D. 43.8.2.9. Ulpianus libro sexagensimo octavo ad edictum: Si quis in mari piscari aut navigare prohibeatur, non habebit interdictum, quemadmodum nec is, qui in campo publico ludere vel in publico balineo lavare aut in theatro spectare arceatur: sed in omnibus his casibus iniuriarum actione utendum est. - „Jeśli komuś nie pozwolono łowić ryb w morzu albo żeglować, nie będzie miał on interdyktu, podobnie jak ten, komu zabroniono gry na publicznym placu albo kąpieli w publicznej łaźni czy oglądania widowisk w teatrze. We wszystkich tych przypadkach należy skorzystać ze skargi z tytułu umyślnego naruszenia cudzej osobowości".

Czyny polegające na uniemożliwianiu rybołówstwa czy żeglugi rzecznej spotykały się z reakcją pretora $\mathrm{w}$ interdykcie ut in flumine publico navigare liceat (,,aby umożliwiono żeglugę na rzece publicznej") ${ }^{17}$. Podobne działania, które miały miejsce na morzu, mogły stanowić podstawę do wniesienia actio iniuriarum.

Dopuszczalność zastosowania actio iniuriarum jest wynikiem twórczej pracy rzymskiej jurysprudencji. Informacje o kontrowersji przekazuje nam Ulpian, podkreślając autorytet Pomponiusza.

D. 47.10.13.7. Ulpianus libro quinquagensimo septo ad edictum: Si quis me prohibeat in mari piscari vel everriculum (quod Graece oayn் dicitur) ducere, an iniuriarum iudicio possim eum convenire? Sunt qui putent iniuriarum me posse agere: et ita Pomponius et plerique esse huic similem eum, qui in publicum lavare vel in cavea publica sedere vel in quo alio loco agere sedere conversari non patiatur, aut si quis re mea uti me non permittat: nam et hic iniuriarum conveniri potest. (...) Et quidem mare commune omnium est et litora, sicuti aer, et est saepissime rescriptum non posse quem piscari prohiberi: sed nec aucupari, nisi quod ingredi quis agrum alienum prohiberi potest (...) - „Jeśli ktoś zabrania mi łowienia ryb w morzu

\footnotetext{
16 Na temat wykorzystania tzw. Lex sane si maris w argumentacji w konflikcie między Wenecją a Genuą zob. Fredona (2018).

17 D. 43.14.1. Ulpianus libro sexagensimo octavo ad edictum. pr.: Praetor ait: "Quo minus illi in flumine publico navem ratem agere quove minus per ripam onerare exonerare liceat, vim fieri veto. Item ut per lacum fossam stagnum publicum navigare liceat, interdicam". - „Pretor stanowi: „zabraniam stosowania przemocy, by powstrzymać kogoś przed płynięciem statkiem lub łodzią po rzece publicznej bądź by uniemożliwić komuś załadunek lub rozładunek przy jej brzegu. Nakazuję również umożliwienie żeglugi przez publiczne jezioro, kanał, staw".
} 


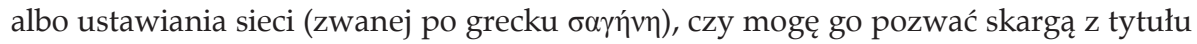
umyślnego naruszenia cudzej osobowości? Są tacy juryści, którzy uważają, że mogę wystąpić z powództwem, a wśród nich Pomponiusz. Wielu sądzi, że podobny jest również przypadek osoby, której nie dopuszcza się do kąpieli w publicznej łaźni czy zasiadania na widowni teatru albo też nie pozwala się w jakimś innym miejscu znajdować się, zajmować miejsce, przebywać, a także jeśli ktoś zabrania mi używania mojej własnej rzeczy. (...) Nie ulega wątpliwości, że morze jest wspólną rzeczą wszystkich, tak jak brzegi i jak powietrze, wydawano zatem bardzo często reskrypty, że nikomu nie wolno zakazywać łowienia ryb ani chwytania ptaków, chyba że zabroniono komuś wstępu na cudzy teren (...)".

Problemem, nad którym dyskutowali rzymscy juryści, była kwestia rozszerzenia zastosowania actio iniuriarum na sytuacje, w których jednostka pozbawiona była możliwości korzystania z rzeczy należących do res communes omnium. Ulpian podkreśla, że zastanawiano się również nad zastosowaniem tego środka do sytuacji modelowej, a więc służącej ochronie korzystania przez jednostki z dóbr publicznych, takich jak łaźnie, teatry czy nawet sposobności korzystania z własnej rzeczy ${ }^{18}$. Daje też dwa argumenty wynikające z auctoritas. Pierwszy, przywołujący opinię Pomponiusza za przyznaniem skargi, drugi - podkreślający istnienie reskryptów cesarskich dotyczących kwestii łowienia ryb (morskich) i chwytania ptaków, jako zasobów naturalnych pochodzących z morza i powietrza, a więc rzeczy wspólnej dla wszystkich ludzi. Niewątpliwie, reakcja części jurysprudencji na zakazy korzystania z res communes omnium w postaci udostępnienia powództwa z tytułu zniewagi świadczy o dostrzeżeniu problemu i pomysłowości we wprowadzeniu adekwatnego środka prawnego.

\section{Wnioski}

W prawie rzymskim nie przewidziano środków prawnych służących wyłącznie ochronie swobody żeglugi czy możności korzystania z zasobów morza.

Morze i brzegi morskie należały do kategorii rzeczy, z których użytek czerpać mogli wszyscy ludzie (res communes omnium). Uzasadnieniem dla takiego uprawnienia jednostki było prawo naturalne, nakazujące odmienne traktowanie rzeczy, które istniały już przed założeniem państwa (primum a natura prodita sunt). Od rzeczy leżących w użytku publicznym odróżniało ich to, że nie można było ich wyłączyć z powszechnego użytku.

Dostrzegano jednak potrzebę zapobiegania sytuacjom konfliktowym związanym z eksploatacją morza i jego zasobów, a nadto w interesie państwa leżało wspieranie rozwoju żeglugi przybrzeżnej. Instrumentem prawnym, który umożliwiał elastyczną ochronę prawną, okazały się interdykty: stosowany w oparciu o model prohibitoryjnego ne quid in loco publico; ne quid in mari inve litore, chroniący

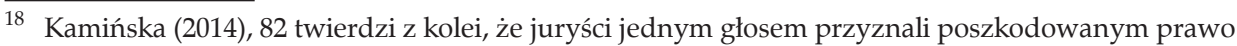
do wniesienia actio iniuriarum.
} 
prawo do korzystania z portu, przybijania do brzegu i swobodę żeglugi oraz uti possidetis, stosowany w przypadku długotrwałego korzystania - najprawdopodobniej o charakterze ekonomicznym - z danego odcinka morza. Na przypadki zakazu żeglugi czy korzystania z zasobów morza - dostrzegając problem w kontekście naruszenia swobody jednostki, zareagowano, wprowadzając ochronę wynikającą z actio iniuriarum.

\section{Literatura}

Arangio-Ruiz, V. (2012), Istituzioni di diritto romano, Napoli.

Biondi, B. (1954), Le servitú prediali nel ditritto romano, Milano.

Biscardi, A. (2002), La tutela interdittale ed il relativo processo. Corso di lezioni (a cura e con con una nota di lettura di Remo Martini), Rivista di Diritto Romano 2, s. 9-98.

Capogrosso Colognesi, L. (1971), Interdetto, [w:] F. Calasso (ed.), Enciclopedia del diritto, vol. 21, Milano, s. 901-928.

Casola, M. (2017), Il mare bene di tutti: universalità del suo uso, Ius Romanum 2, s. 294-311.

Dajczak, W. (1998), Zwrot bona fides w rozstrzygnięciach dotyczących kontraktów u prawników rzymskich okresu klasycznego, Torun.

Di Lella, L. (2004), La tutela interdittale dei luoghi pubblici, [w:] Espaces intégrés et ressources naturelles dans l'Empire romain. Actes du colloque de l'Université de Laval - Québec (5-8 mars 2003), Besançon, s. 193-196.

Fiorentini, M. (1986), Sulla rilevanza economica delle ville maritime durante la Repubblica e l'impero, Index 24, s. 143-198.

Fiorentini, M. (2003), Fiumi e mari nell'esperienza giuridica romana. Profili di tutela processuale e di inquadramento sistematico, Milano.

Fredona, R. (2018), Angelo degli Ubaldi and the Gulf of the Venetians: Custom, Commerce, and the Control of the Sea before Grotius, [w:] R. Fredona, S.A. Reinert (eds.), New Perspectives on the History on Political Economy, Cham, s. 29-73.

Gandolfi, G. (1955), Contributo allo studio del processo interdittale romano, Milano.

Grosso, G. (1974), Problemi sistematici del diritto romano. Cose-Contatti, Torino.

Lafont, X. (2001), Villa maritima. Recherches sur la villa littoriales de l'Italie romaine, Roma.

Kamińska, R. (2014), Swoboda korzystania z miejsc publicznych na przykładzie morza i wybrzeża morskiego, Zeszyty Prawnicze [UKSW] 14.2, s. 63-83.

Kamińska, R. (2017), Private and public interest in the 'interdictum ne quid in loco publico fiat', Zeszyty Prawnicze [UKSW] 17.4, s. 197-215.

Klingenberg, G. (2004), Maris prioprium ius in D. 47.10.14, RHD 37, s. 37-60.

Lenel, O. (1927), Das Edictum perpetuum, Leipzig.

Luzzato, G.I. (2004), Problema d'origine del processo extra ordinem, 1: Premesse di metodo, i cosidetti rimedi pretori, Bologna.

Maddalena, P. (2012), I beni communi nel diritto romano: qualche valida idea per gli studiosi moderni, Rivista di diritto pubblico italiano, communitario e comparato 14.2, https:// www.federalismi.it/nv14/articolo-documento.cfm?artid =20444.

Ortu, R. (2017), Plaut. Rud. 975 «Mare quidem commune certost omnibus», JusOnline 2, s. 161-170.

Purpura, G. (2004), 'Liberum mare', acque territoriali e riserve di pesca nel mondo antico, ASGP 49, www1.unipa.it/.../2004/...Purpura\%20-\%20Liberum\%20mare.pdf. 
Sini, F. (2008), Persone e cose: res communes omnium. Prospettive sistematiche tra diritto romano e tradizione romanistica,Diritto@Storia. Rivista Internazionale di Scienze Giuridiche e Tradizione Romanistica 7, http://dirittoestoria.it/7/Tradizione-Romana/Sini-Personecose-res-communes-omnium.htm.

Sitek, B. (1999), 'Actiones populares' w prawie rzymskim na przełomie republiki i pryncypatu, Szczecin.

Talamanca, M. (1990), Istituzioni di diritto romano, Milano.

\section{Bartosz Szolc-Nartowski}

\section{INTERDICTIVE PROTECTION OF THE FREEDOM OF NAVIGATION AND SEA RESOURCES IN ROMAN LAW}

The Author presents issues related to the legal status of the sea and its shores in ancient Rome, the course of interdict proceedings and individual interdict as legal tools developed by the Roman jurisprudence and praetor to protect the freedom of sea navigation and the use of sea coasts and sea resources. 